\title{
A Taxonomy of Organizational Justice Theories
}

\author{
JERALD GREENBERG \\ Ohio State University
}

\begin{abstract}
A taxonomy is presented that categorizes theories of organizational justice with respect to two independent dimensions: a reactiveproactive dimension and a process-content dimension. Various theories within each of the four resulting categories are identified. The implications of the taxonomy are discussed with respect to clarifying theoretical interrelationships, tracking research trends, and identifying needed areas of research.
\end{abstract}

Stimulated by conceptualizations of justice in organizations by such theorists as Homans (1961), Adams (1965), and Walster, Berscheid, and Walster (1973), organizational researchers devoted considerable attention in the 1960s and 1970s to testing propositions about the distribution of payment and other work-related rewards derived from equity theory (for reviews, see Campbell \& Pritchard, 1976; Greenberg, 1982). Although reviews and critiques of equity theory once dominated the pages of organizational journals (e.g., Goodman \& Friedman, 1971; Pritchard, 1969; Weick, 1966), more recently it has been the subject of far less attention (Reis, 1986). It would be a mistake, however, to view this trend as an indication that organizational scientists are less interested in matters of justice and fairness in organizations than they used to be. Indeed, concerns about fairness have been expressed in such organizational domains as conflict resolution (Aram \& Salipante, 1981), personnel selection (Arvey, 1979), labor disputes (Walton \& McKersie, 1965), and wage negotiation (Mahoney, 1975), to name just a few. Although research inspired by equity theory has slowed down greatly, there have emerged a variety of different approaches to justice that are at least as useful in explaining behavior in a broader variety of organizational contexts. Because there has been a proliferation of such newer approaches and because these may be less familiar to organizational scientists, the present paper will categorize various conceptualizations of justice around a taxonomic scheme. This taxonomy will not only offer a parsimonious way of organizing these various conceptualizations, but in so doing, will highlight their interrelationships and their importance to the study of organizations.

\section{Dimensions of the Taxonomy}

The present taxonomy is derived by combining two conceptually independent dimensions: a reactive-proactive dimension and a processcontent dimension. It is not assumed that these are the only organizing dimensions that may be identified. Indeed, it is possible that different taxonomic schemes may be proposed that are based on completely different conceptual dimensions. However, the dimensions identified in the present taxonomy appear to be very useful ones for organizing a wide range of conceptualizations of interest in the field of organizational behavior.

\section{Reactive-Proactive Dimension}

The reactive-proactive dimension was suggested by a distinction made by Van Avermaet, McClintock, and Moskowitz (1978), and was used 
to organize the equity theory literature by Greenberg (1982). The distinction is between seeking to redress injustice and striving to attain justice.

A reactive theory of justice focuses on people's attempts either to escape from or to avoid perceived unfair states. Such theories examine reactions to injustices. By contrast, proactive theories focus on behaviors designed to promote justice. They examine behaviors attempting to create just states.

\section{Process-Content Dimension}

The second dimension, the process-content dimension, was inspired by legal research distinguishing between the way verdicts are derived and what those verdicts are (Walker, Lind, \& Thibaut, 1979). Mahoney (1983) made a similar distinction by differentiating between the processes by which wages are determined and the outcome of those processes. As such, we may distinguish between approaches to justice that focus on the ends achieved and the means used to acquire those ends.

A process approach to justice focuses on how various outcomes (in organizations, pay and recognition are good examples) are determined. Such orientations focus on the fairness of the procedures used to make organizational decisions and to implement those decisions. In contrast, content approaches concern themselves with the fairness of the resulting distribution of outcomes. These perspectives address the relative fairness of the outcomes received by various organizational units (typically either individuals or groups).

\section{Identifying Theories Within the Taxonomy}

It is assumed that the reactive-proactive dimension and the process-content dimension are independent of each other, thereby yielding four distinct classes of justice conceptualizations when the two dimensions are combined. Table l organizes these approaches and identifies a primary exemplar of each.
Two points must be made regarding the theories in this taxonomy. First, no attempt has been made to be exhaustive. Instead, the theories identified and described are ones that are either wellestablished or promising ones within psychology or sociology, fields within which the study of justice in organizations traditionally has been rooted. Limiting the examples does not imply that other theories would not fit in. Rather, in view of the clarifying function of the present work, excluding them is more reflective of a judgment regarding the limitations of their demonstrated or potential value for organizational study.

Second, although some of the theories classified by the present taxonomy have been widely applied to organizational contexts, none were formulated with organizations in mind as their exclusive focus. Even Adams's (1965) popular theory of inequity, originally tested in work settings, has been described as a general theory of social behavior (Walster et al., 1973). Other theories presented here originated within the legal milieu (e.g., Thibaut \& Walker, 1975). Nonetheless, because the theories have been, or are now being used to explain organizational behavior, they will be referred to collectively as theories of organizational justice.

Table 1

Taxonomy of Organizational Justice Theories with Corresponding Predominant Exemplars

\begin{tabular}{lll}
\hline \multirow{2}{*}{$\begin{array}{l}\text { Reactive- } \\
\text { Proactive } \\
\text { Dimension }\end{array}$} & \multicolumn{2}{c}{ Content-Process Dimension } \\
\cline { 2 - 3 } & \multicolumn{1}{c}{ Content } & \multicolumn{1}{c}{ Process } \\
\hline Reactive & $\begin{array}{l}\text { Reactive Content } \\
\text { Equity theory } \\
\text { (Adams, 1965) }\end{array}$ & $\begin{array}{l}\text { Reactive Process } \\
\text { Procedural justice } \\
\text { theory (Thibaut } \\
\text { \& \& Walker, 1975) }\end{array}$ \\
& $\begin{array}{l}\text { Proactive Content } \\
\text { Justice judgment } \\
\text { theory (Leventhal } \\
\text { (1976a, 1980) }\end{array}$ & $\begin{array}{l}\text { Proactive Process } \\
\text { Allocation preference } \\
\text { theory (Leventhal, } \\
\text { Karuza, \& Fry, 1980) }\end{array}$ \\
\hline
\end{tabular}




\section{Reactive Content Theories}

Reactive content theories are conceptual approaches to justice that focus on how individuals respond to unfair treatment. Organizational scientists are probably most familiar with this class of justice theory because most popular conceptualizations of justice in organizations fall within this category. Included among these theories are Homans's (1961) theory of distributive justice, and Adams's (1965) and Walster et al.'s (1973) versions of equity theory (see also Walster, Walster, \& Berscheid, 1978). Despite several differences in the specifics of their formulation (see Cohen \& Greenberg, 1982), these theories share an important common orientation in explicitly stating that people will respond to unfair relationships by displaying certain negative emotions, which they will be motivated to escape by acting so as to redress the experienced inequity. It is this aspect of the theories that qualifies them as reactive content theories: They focus on how people react to unfair distributions of rewards and resources.

Conceptually rooted in the tradition of balance theories popular in the 1950s and 1960s (e.g., Festinger, 1957; Heider, 1958) these approaches to justice conceptualized "equitable," or "distributively just" relations as ones in which there was an equal balance between the ratio of a person's contributions and his or her outcomes. Unequal balances, such as those that existed whenever workers were either overpaid or underpaid relative to another person with equal contributions, were assumed to be unpleasant, which were theorized to prompt changes in job satisfaction and/or performance. In particular, Adams's (1965) theory of inequity, the approach that inspired most of the justice-related research in organizational settings, specified that overpaid workers would feel "guilty" and that underpaid workers would feel "angry." These negative states were expected to motivate behavioral and/or attitudinal changes on the part of the workers involved that altered, either behaviorally or perceptually, the relationship between their own and another's contributions and outcomes (cf., Greenberg, 1984). For example, work- ers perceiving an inequitable state may react behaviorally by altering their performance levels, and/or cognitively by attempting to justify the outcomes received (Walster et al., 1978).

It was, no doubt, because the theoretical metrics were so explicitly suited to work-related exchanges that equity theory became so popularly applied to organizational research. Indeed, it was within simulated work settings that most of the research on equity theory was conducted (e.g., Lawler \& O'Gara, 1967; Pritchard, Dunnette, \& Jorgenson, 1972). In the prototypical test of equity theory, the experimenter manipulated inequity by leading worker-subjects to believe that the basis for their payment was unfairthereby creating either "underpayment inequity" or "overpayment inequity." For example, this may have included: (a) leading subjects to believe that an error occurred that caused them to receive the same wage as their more qualified co-workers, thereby manipulating overpayment (e.g., Adams \& Rosenbaum, 1962), or (b) allowing subjects to discover through conversations with co-workers that they were equally qualified but unequally paid (e.g., Garland, 1973).

Typically, performance on some work taskpopularly a proofreading task for which quantity and quality measures could be taken-constituted the dependent variable. According to equity theory, underpaid workers should be less productive and less satisfied than equitably paid workers and overpaid workers should be more productive and less satisfied than equitably paid workers. In general, and over a wide variety of experimental settings, support was found for these predictions (for a review, see Greenberg, 1982).

Several sociological theories that have developed in response to certain aspects of Adams's conceptualization, particularly the nature of social comparisons, also should be included within the category of reactive content theories. Among these is the status value version of equity theory proposed by Berger and his associates (Anderson, Berger, Zelditch, \& Cohen, 1969; Berger, Zelditch, Anderson, \& Cohen, 1972). 
According to this formulation, a person's feelings of inequity and reactions to inequity result not from comparisons made to a specific other person (referred to as a "local comparison"), but from comparisons to a generalized other (referred to as a "referential comparison"), such as an occupational group. Extending this approach, Jasso's (1980) theory of distributive justice ignored the outside comparisons in justice evaluations altogether, and defined justice in terms of the comparisons people make between their actual share of goods and their beliefs about a "just share." Despite some important conceptual differences between these theories and the more familiar Adams formulation, their similar focus on how people react to beliefs about the unfair distribution of outcomes (regardless of the comparative basis on which these judgments are formed) allows these theories to be clearly categorized as reactive content theories.

More closely related to traditional equity theory, and the final reactive content theory of justice to be identified, is the theory of relative deprivation (Crosby, 1976). Based on findings dating back to World War II (Stouffer, Suchman, DeVinney, Star, \& Williams, 1949), but also more recently examined in organizational contexts (Crosby, 1984; Martin, 1981), the relative deprivation orientation to justice is becoming increasingly more popular among organizational scientists. In its most general form, the relative deprivation approach asserts that certain reward distribution patterns will encourage people to make certain social comparisons, which will lead to feelings of deprivation and resentment, causing a variety of reactions ranging from depression through the outbreak of violent riots (Martin, 1981).

The term "relative deprivation," first used by Stouffer et al. (1949), refers to the counterintuitive finding that black soldiers stationed in the south felt more satisfied with military life than black soldiers stationed in northern bases despite socioeconomic conditions being more favorable in the north. These effects were attributed to the tendency for black soldiers in the south to feel more privileged than their civilian counterparts in the south, whereas, black soldiers in the north felt relatively less privileged than their civilian counterparts in the north. Although most of the subsequent relative deprivation research focused on violent attempts to change political systems (Crosby, 1976), some efforts have focused on how aggrieved employees react to organizationally induced discontent (Martin, 1981). For example, large-scale survey studies by Crosby $(1982,1984)$ found that working women, especially those in high prestige jobs, who although they may be more advantaged than nonworking women, tend to be more aggrieved because they compare themselves to working men, relative to whom they are less advantaged. Research of this type is typical of that generated today by relative deprivation theory. Because it examines how people will respond to perceived unfair reward distributions, relative deprivation theory clearly can be identified as a reactive content theory.

\section{Proactive Content Theories}

In contrast to reactive content theories, which focus on how workers respond to fair and unfair outcome distributions, proactive content theories focus on how workers attempt to create fair outcome distributions. The major theoretical statements in this category have come from Leventhal (1976a, 1980), who in the late 1960s and early 1970s conducted a series of laboratory studies in which the basic pattern of independent and dependent variables found in traditional reactive accounts of justice were reversed. That is, Leventhal and his associates typically manipulated concerns about justice (through appropriate instructional sets) to examine their impact on reward allocation decisions (for reviews, see Freedman \& Montanari, 1980; Mikula, 1980).

Leventhal (1976b) contended that people sometimes proactively strive to create equitable distributions of reward-those in which the rewards received are proportional to the contributions made-because these will be the most beneficial to all concerned parties in the long run. Indeed, many studies (e.g., Greenberg \& Leventhal, 1976; Leventhal \& Michaels, 1969) have shown that allocators often divide resources equitably between recipients (for reviews, see Adams 
\& Freedman, 1976; Freedman \& Montanari, 1980). However, additional research has shown that allocators of rewards sometimes distribute those rewards in ways that violate the equity norm-such as by distributing rewards equally, or in accordance with recipients' needs (Schwinger, 1980). Recognizing that such violations of the equity norm may be completely fair under appropriate circumstances, Leventhal (1976a, 1980) formulated his justice judgment model. This model proposed that individuals attempt to make fair allocation decisions by variously applying several possible allocation rules to the situations they confront. For example, in situations in which the importance of maintaining social harmony between group members is stressed, the perceived fair allocation practice would call for following the equality norm-dividing rewards equally regardless of possible differential contributions among recipients (Deutsch, 1975).

Whereas Leventhal's approach to reward allocation practices is instrumental in character, another proactive content theory of justice, Lerner's (1977; Lerner \& Whitehead, 1980) justice motive theory is decidedly more moralistic. Lerner (1982) argued that justice is the preeminent concern of human beings and the quest for justice as a means to a profit-maximizing end (as Leventhal proposed) is a mythical illusion. Like Leventhal, however, Lerner recognized that allocation practices often go beyond the possibility of proportional equity. In fact, Lerner identified four principles that are commonly followed: (a) competition-allocations based on the outcome of performance, (b) parity-equal allocations, (c) equity - allocations based on relative contributions, and (d) Marxian justice-allocations based on needs.

Briefly, justice motive theory stipulates that the form of justice that will be followed in making allocation decisions will depend on the nature of the relations between the parties involved in conjunction with the focus of the parties on each other as individuals or as occupants of positions. For example, the theory predicts that an individual reacting to a close friend as an individual will emphasize that person's needs when mak- ing an allocation decision. Similarly in more distant relationships, people are expected to follow the parity norm when the other is recognized as an individual, and the equity norm when reacting to the other as a role incumbent. Research relating various reward allocation practices to the nature of the relationship between people has been supportive of justice motive theory (e.g., Carles \& Carver, 1979).

Despite some differences in underlying philosophies, both justice judgment theory and justice motive theory make similar predictions about how people will allocate rewards under various circumstances-predictions that largely have been supported by research (for a review, see Deutsch, 1985). Both of these approaches clearly qualify as proactive content theories of justice because they deal with how people seek to make decisions about the allocation of reward.

\section{Reactive Process Theories}

Although it appears that theories focusing on the fairness of the processes used to make decisions (process theories) do not differ appreciably from those theories focusing on the fairness of the resulting decisions (content theories), this is not the case because process theories stem from a different intellectual tradition-in particular, the law. In fact, legal scholars have commonly accepted that the procedures used to make judicial decisions will have a profound influence on the public's acceptance of them (Fuller, 1961).

At approximately the same time when proactive content theories were formalized and researched (the early 1970s) a team of researchers at the University of North Carolina, John Thibaut and Laurens Walker, influenced by the tradition of research on legal procedures, undertook a series of investigations designed to compare reactions to various dispute resolution procedures (for a review, see Thibaut \& Walker, 1975). Their theory of procedural justice distinguished between three parties: two disputants (such as the litigants in a court case), and an intervening third party (such as a judge); and two stages of the dispute-resolution process: the process stage, during which evidence is presented, and the 
decision stage, during which the evidence is used to resolve the dispute. The ability to control the selection and development of the evidence used to resolve the dispute is referred to as process control; the ability to determine the outcome of the dispute itself is referred to as decision control (Thibaut \& Walker, 1978).

The procedures used can vary regarding the degree of control the various parties have over each stage. In particular, procedures may be identified that give third parties control over: both outcomes and procedures, autocratic procedures; decisions but not processes, arbitration procedures; processes but not decisions, mediation procedures; and neither processes nor procedures, bargaining procedures. Finally, moot procedures are those in which the disputants and third parties share control over outcomes and processes. (Recently, Sheppard, 1984, has proposed a more extensive system.)

Although reactions to all of these procedures were assessed, Thibaut and Walker were most interested in comparing autocratic and arbitration procedures because these most closely distinguished between the major legal systems. For example, the adversary system, used in American and British courts, gives judges control over the verdict but leaves the process (e.g., selection of attorneys, presentation of evidence) in the hands of the disputants themselves. However, the inquisitorial system, used in continental Europe, gives judges control over the collection and presentation of evidence as well as the verdicts. The theory is concerned with how people will react to each of these decision-making procedures, thereby qualifying as a reactive process theory. The theory predicts that both litigants and observing disinterested parties will be more satisfied with procedures giving them process control (e.g., the adversary system) than those that do not (e.g., the inquisitorial system). The verdicts resulting from procedures offering process control are hypothesized to be perceived as fairer and to be better accepted than those resulting from procedures denying process control. Many studies using a simulated legal decision-making methodology (e.g., Lind, Kurtz,
Musante, Walker, \& Thibaut, 1980; Walker, Lind, \& Thibaut, 1979) have supported this claim (for reviews, see Folger \& Greenberg, 1985; Thibaut \& Walker, 1975). Interestingly, procedures giving diputants a voice in the decision-making process tend to enhance the acceptance of even unfavorable decisions (LaTour, 1978; Lind et al., 1980.)

Other research has generalized the Thibaut and Walker findings to less formal settings. For example, Tyler and his associates found that reactions to encounters with police officers (Tyler \& Folger, 1980), politicians, and teachers (Tyler \& Caine, 1981) also are heavily influenced by the procedures that these authorities follow in treating their clients. Recently, organizational researchers have actively attempted to extend and apply Thibaut and Walker's theory of procedural justice to a variety of organizational contexts, such as the resolution of labor disputes (Sheppard, 1984) and the appraisal of job performance (Greenberg, 1986a, 1986b), among others (for reviews, see Folger \& Greenberg, 1985; Greenberg \& Folger, 1983; Greenberg \& Tyler, in press).

\section{Procctive Process Theories}

Of the theories identified in this taxonomy, probably the least well-known fall into the proactive process category. The predominant theoretical position within this category is Leventhal, Karuza, and Fry's (1980) allocation preference theory. This is an outgrowth of Leventhal's (1976a, 1980) justice judgment model (described earlier) and is proposed as a general model of allocation behavior. However, because the theory has been applied almost exclusively to procedural decisions rather than distributive ones (e.g., Fry \& Cheney, 1981; Fry \& Leventhal, 1979), it has operated as a proactive process theory. Thus, in contrast with the emphasis on dispute-resolution procedures typical of the reactive process theories, the proactive process orientation tends to focus on allocation procedures. By using this orientation, one seeks to determine what procedures people will use to achieve justice. 
Allocation preference theory asserts that allocation procedures will be preferred to the extent that they help the allocator attain valued goals, including the attainment of justice. In particular, the theory proposes that people hold expectancies that certain procedures will be differentially instrumental in meeting their goals, and that the procedure believed to be most likely to help attain one's goal will be the most preferred one. Eight procedures are identified that may help promote the attainment of justice. These include procedures that: ( $\alpha$ ) allow opportunities to select the decision-making agent, (b) follow consistent rules, (c) are based on accurate information, (d) identify the structure of decision-making power, (e) employ safeguards against bias, (f) allow for appeals to be heard, (g) provide opportunities for changes to be made in procedures, and (h) are based on prevailing moral and ethical standards.

The limited research inspired by allocation preference theory offers general support for it. The studies have been of two types-those in which the subjects respond to open-ended requests for examples of perceived fair or unfair procedures, and those in which subjects rate the importance of various allocation procedures manipulated in written scenarios. In one openended questionnaire study, Sheppard and Lewicki (in press) asked white-collar managers to identify unfair incidents across a variety of managerial roles. Among other principles, they found that subjects identified consistency, bias suppression, correctability, and ethicality, all principles of procedural justice proposed by Leventhal et al. (1980).

Similarly, Greenberg (1986a) asked middle managers to identify determinants of perceived fair performance evaluations, and found procedural determinants consistent with Leventhal et al.'s (1980) theory, namely: (a) the soliciting of workers' input prior to evaluations and using it as the basis of evaluations, (b) the availability of two-way communication during appraisal interviews, (c) the opportunity to challenge/rebut the evaluation received, (d) the degree of the evaluator's familiarity with the ratee's work, and (e) the consistent application of evaluation standards.

Finally, in several role-playing investigations Fry (Fry \& Cheney, 1981; Fry \& Leventhal, 1979) found that consistency was believed to be the most important procedural determinant of fairness across a variety of allocation settings. In a more extensive study, Barrett-Howard and Tyler (1986) confirmed that consistency was a powerful determinant of perceived fairness across a wide variety of situations and social relationships. However, the other procedural elements identified by Leventhal et al. (1980) were found to be perceived as differentially important as determinants of fairness in different types of social relationships.

\section{Implications of the Taxonomy}

The present taxonomy serves several useful functions. Among these are its ability: (a) to clarify conceptual interrelationships, (b) to track trends in organizational justice research, and (c) to identify needed areas of research and conceptual development.

\section{Clarifying Conceptual Interrelationships}

Given the proliferation of research and theory about organizational justice, the present taxonomy is a useful clarifier. By showing how the various theories are distinct and interrelated, the taxonomy provides a schema for conceptually organizing a growing body of work. One result of such a framework is reduced conceptual confusion.

An important beneficial effect of this clarifying role is that it encourages researchers to be cognizant of existing conceptualizations and to apply the most useful ones to their own work. In the absence of such a taxonomy, it is too easy for researchers to use terms and apply concepts in ways that fail to incorporate existing precedents, thereby potentially adding confusion to the literature.

To illustrate this point, consider the recent program of research on "workplace justice" by Dalton and Todor (1985a, 1985b). In several archival 
studies, these researchers uncovered evidence that females were more preferentially treated than males in grievance-resolution settings. These findings of objective differences in outcome distributions were then taken as evidence of differences in "workplace justice outcomes." Although it is conceivable that these findings reflect perceived unfair states, it is not possible to conclude from the Dalton and Todor data that subjective feelings of unfairness resulted from the objective outcomes identified. Because this was not their intent, and because they make no such claim, the investigators cannot be faulted.

However, the point is that they are using the term "justice" in a way that is not in keeping with a voluminous literature that emphasizes justice as a subjective state or quality. This is not to say that new, more objectively defined perspectives are without merit, but simply that current researchers on organizational justice should be aware of previous conceptual advances, such as those identified through the present taxonomy.

\section{Tracking Trends in Organizational Justice Research}

The present taxonomy identifies trends in the questions about justice posed in organizational research. A summary of the representative questions asked by researchers developing the vari- ous types of theories and the corresponding dependent measures used appears in Table 2.

Although there have been some recent investigations inspired by equity theory (e.g., Greenberg \& Ornstein, 1983) and some conceptual clarifications (e.g., Cosier \& Dalton, 1983), it is clear that interest in reactive content approaches has waned (Reis, 1986). Instead the emphasis has been on more proactive and more processoriented conceptualizations. In essence, then, two shifts are identified-a shift from reactive to proactive theories and a shift from content to process theories.

In reaction to the reactive approach of Adams's work in the 1960s (e.g., Adams \& Rosenbaum, 1962) investigators such as Leventhal (Leventhal \& Michaels, 1969) and Messé (1971) pioneered a more proactive approach in the late 1960s and early 1970s. With this, there was a shift from asking how workers reacted to inequitable payments to how they attempted to create equitable payments. Research of this proactive content type continues, and is especially popular among European social scientists. For example, recent representative efforts have focused on issues such as: (a) the distinctions allocators make between various types of contributions in making fair allocations (Tornblom \& Jonsson, 1985), (b) the commitment to justice principles among different classes of people (Montada, Schmitt, \& Dalbert, 1986),

Table 2

Representative Research Questions and Dependent Measures for Each Type of Organizational Justice Theory

\begin{tabular}{lll}
\hline Type of Theory & Representative Question & Prototypical Dependent Measures \\
\hline Reactive Content & $\begin{array}{l}\text { How do workers react to inequitable } \\
\text { payments? }\end{array}$ & $\begin{array}{l}\text { Reactions to overpayment or underpayment } \\
\text { inequity (reviewed by Greenberg, 1982) }\end{array}$ \\
Proactive Content & $\begin{array}{l}\text { How do workers attempt to create fair } \\
\text { payments? }\end{array}$ & $\begin{array}{l}\text { Adherence to justice norms in reward allocations } \\
\text { (reviewed by Freedman \& Montanari, 1980) }\end{array}$ \\
Reactive Process & $\begin{array}{l}\text { How do workers react to unfair policies } \\
\text { or legal procedures? }\end{array}$ & $\begin{array}{l}\text { Reactions to unfair payment methods or dispute- } \\
\text { resolution methods (reviewed by Folger \& } \\
\text { Proactive Process }\end{array}$ \\
& $\begin{array}{l}\text { How do workers attempt to create fair } \\
\text { policies or procedures? }\end{array}$ & $\begin{array}{l}\text { Perceptions of procedural fairness (reviewed by } \\
\text { Lind \& Tyler, in press) }\end{array}$ \\
\hline
\end{tabular}


and (c) the reliance upon considerations of need in the attainment of justice (Schwinger, 1986). With the continuation of such research there appears to be developing a better understanding of the ways workers behave in the interest of being fair.

When Thibaut and Walker (1975) began their research on procedural justice in the early 1970s, it was not a reaction against the shortcomings of reactive process theories. Rather, it was inspired by an interest in the attributes of various disputeresolution techniques. It was theorists such as Deutsch (1975) and Leventhal (1976b) who first pointed out that procedural justice research may be viewed as an extension of equity theory research into the domain of allocation processes. Folger (1977) was among the first researchers whose work reflected a shift from how workers react to inequitable outcomes to how they react to unfair procedures. His work showed that giving workers the opportunity to have a voice in the decisions affecting them under some conditions enhanced their reactions to the outcome of those decisions (for a review, see Greenberg \& Folger, 1983).

The question of how workers react to various organizational procedures is not only the newest one to interest organizational justice researchers, but also one of the most actively researched areas today (for a statement on the state of the science, see Greenberg \& Tyler, in press). Indeed, the attention procedural justice has received in recent professional symposia (e.g., Folger, 1986) and special publications devoted to the topic (Greenberg \& Tyler, in press; Lind \& Tyler, in press) attests to the current high level of interest in applying proactive process orientations to the study of organizational justice. As more organizational researchers continue to develop a rapprochement between their interests and a process orientation to justice, there has been a shift away from legal-based questions regarding fair procedures to more organizationally based questions. The growing body of research and theory considering these questions promises to extend our knowledge of organizational justice.
For example, the present taxonomy proves to be useful in tracing the conceptual roots of two rapidly evolving and related lines of theory development in organizational justice. One of these, Folger's (1986, in press) referent cognitions theory, expands upon relative deprivation theory and equity theory when explaining relative satisfaction with work outcomes. The theory extends the reactive content orientation of its predecessors by distinguishing between two types of reactions-those based on relative comparisons, leading to feelings of (dis)satisfaction, and those based on beliefs about what should have happened, leading to feelings of resentment and moral outrage. Resentment reactions are theorized to be based on the procedures used to bring about various outcomes, whereas satisfaction with those outcomes is based on beliefs about the relative outcome levels themselves. In terms of the present taxonomy, it can be said that referent cognitions theory expands the concept of relative deprivation to a process prospective beyond its more traditional, content perspective.

Similarly, related research by Bies (1987; Bies \& Moag, 1986) focuses on feelings of moral outrage. Bies asserts that justice perceptions are better explained by the social accounts given for them than by the appearance of an inequity based on comparisons of relative outcomes and inputs. Social accounts of events-including those that claim mitigating circumstances, invoke superordinate ideological goals, refer to likely future states, and offer apologies for current states-are offered as likely determinants of reactions to injustice. Bies also claims that social accounts can be used to explain reactions to outcome distribution procedures as well as the outcome distributions themselves. As such, Bies's conceptualization, like Folger's, provides a framework for integrating process-based and the content-based reactions to injustice. In addition, Bies's work sheds some light on an important deficiency of reactive theories of organizational justice-namely, the conditions under which different reactions are likely to be exhibited. 
The present taxonomy helps us recognize the conceptual traditions from which new theoretical developments, such as those of Folger (1986) and Bies (1987) were derived, and as such facilitates appreciation for their integrative nature. Thinking of these developments as markers of justice theories, the taxonomy may be viewed as a road map that helps chart the course of theoretical progress.

\section{Identifying Needed Āreas of Research and Theory}

By highlighting the relationships between the various types of organizational justice theories, the present taxonomy helps identify areas of theoretical and empirical deficiency. In particular, it helps spot research areas across categories in which parallel types of investigations have not been undertaken. Most notable are questions stemming from the proactive process orientation. In the abstract, this should not be surprising given that the proactive process approach is the newest theoretical approach to organizational justice. However, questions should be asked about the type of research that needs to be conducted in this area relative to that which already has been done. As described earlier, in studies inspired by the proactive process, subjects were asked either to generate and categorize lists of perceived fair/unfair job behaviors or to assess the importance of various theoretically derived procedural determinants of fairness manipulated in written scenarios. Both types of research essentially serve as validation studies of the research from which they were derived. Although these investigations are useful, they are not parallel to those found in the proactive content category because how subjects make procedural decisions was not observed directly.

Although in proactive content studies the resource allocation decisions made by subjects are observed under a variety of different conditions (see Freedman \& Montanari, 1980), investigators interested in procedural issues have as of yet conducted analogous studies. Indeed, a program of research designed to determine the conditions under which people make vari- ous procedural decisions would be useful to theory development in the proactive process area. Two types of investigations are warranted. First, laboratory studies could be conducted in which personal and situational factors are manipulated to see how they influence decisions about what procedures should be used. Second, a post hoc, policy-capturing investigation could be done in which investigators analyze the conditions under which various actual procedural decisions are made.

One area in which a contribution of the present taxonomy may be realized is pay satisfaction. In particular, Heneman (1985) identified "pay policies and administration" as a class of variables that need to be included in his model of pay satisfaction. Citing evidence (Dyer \& Theriault, 1976; Weiner, 1980) showing that understanding how pay raises were determined added to the explained variance in pay satisfaction beyond pay level alone, Heneman (1985) concluded that "perceptions about how pay is administered do appear to have a bearing on people's pay satisfaction" (p. 132). In making this claim for a direction in which to extend theories of pay satisfaction beyond equity theory, Heneman recognized the distinction between content and process theories of organizational justice articulated here. Heneman's insight may have been realized earlier given the present taxonomy. Still, seeing how well the taxonomy fits Heneman's conceptualization provides encouragement for using it to derive further insight about pay satisfaction. Indeed, process theories of organizational justice may be used to suggest factors likely to enhance satisfaction with pay and the consequences of perceived unfair pay-determination practices.

Finally, it should be noted that the present taxonomy provides a useful framework for appreciating the context within which several newly emerging lines of research are derived. For example, Greenberg's line of research on performance appraisal (Greenberg, 1986b, in press) was inspired by attempts to apply research and theory on procedural justice to employee evaluation situations. Similarly, Sheppard's (1985) efforts at applying his model of organizational 
dispute resolution (1984) were inspired by a tradition of research applying procedural justice notions to legal disputes. Both these lines of research represent areas made salient by the present taxonomy.

\section{Conclusion}

In 1966, Weick referred to equity theory as "among the more useful middle-range theories of organizational behavior" (p. 439). In 1984, Miner classified equity theory among those in his list of "not so useful" theories of organizational behavior. Equity theory has fallen into disfavor partially because of its limited applicability and partially because of its internal validity as a theory (Furby, 1986). Also it may be because researchers have grown weary of the restricted range of questions about organizational justice it addresses. Yet, questions about justice still arise in many organizational milieus, among them contexts as diverse as pay plans (comparable worth) (Mahoney, 1983), grievance procedures, selection and placement practices, and evaluation policies (Folger \& Greenberg, 1985; Greenberg \& Folger, 1983). The questions raised about justice in these contexts are not ones that equity theory, or any of the other reactive content theories, are equipped to address. However, there are other theories of organizational justice presented in this article that may be particularly well-suited to such matters. To the extent that the taxonomy presented in this article has brought them to the attention of organizational researchers, then it has paved the way for increased understanding to emerge-an understanding of various organizational phenomena, and of justice itself.

\section{References}

Adams, J. S. (1965) Inequity in social exchange. In L. Berkowitz (Ed.), Advances in experimental social psychology (Vol. 2, pp. 267-299). New York: Academic Press.

Adams, J. S., \& Freedman, S. (1976) Equity theory revisited: Comments and annotated bibliography. In L. Berkowitz \& E. Walster (Eds.), Advances in experimental social psychology (Vol. 9, pp. 43-90). New York: Academic Press.

Adams, J. S., \& Rosenbaum, W. B. (1962) The relationship of worker productivity to cognitive dissonance about wage inequities. Journal of Applied Psychology, 46, 161-164.

$\rightarrow$ Anderson, B., Berger, J., Zelditch, M., \& Cohen, B. P. (1969) Reactions to inequity. Acta Sociologica, 12, 1-12.

$\rightarrow$ Aram, J. D., \& Salipante, P. F., Jr. (1981) An evaluation of organizational due process in the resolution of employee/ employer conflict. Academy of Management Review, 6, 197-204.

Arvey, R. D. (1979) Fairness in selecting employees. Reading, MA: Addison-Wesley

Barrett-Howard, E. , \& Tyler, T. R. (1986) Procedural justice as a criterion in allocation decisions. Journal of Personality and Social Psychology, 50, 296-304.

Berger, J., Zelditch, M., Anderson, B., \& Cohen, B. P. (1972) Structural aspects of distributive justice: A status-value formulation. In J. Berger, M. Zelditch, \& B. Anderson (Eds.) Sociological theories in progress (Vol. 2, pp. 21-45). Boston: Houghton Mifflin.
Bies, R. J. (1987) The predicament of injustice. The management of moral outrage. In L. L. Cummings \& B. M. Staw (Eds.), Research in organizational behavior (Vol. 9, pp. 289-319). Greenwich, CT: JAI Press.

Bies, R. J., \& Moag, J. S. (1986) Interactional justice: Communication criteria of fairness. In R. J. Lewicki, B. H. Sheppard, \& M. H. Bazerman (Eds.), Research on negotiation in organizations (Vol. 1, pp. 43-55). Greenwich, CT: JAI Press.

Campbell, J. P., \& Pritchard, R. A. (1976) Motivation theory in industrial and organizational psychology. In M. D. Dunnette (Ed.), Handbook of industrial and organizational psychology (pp. 63-130). Chicago: Rand McNally.

Carles, E. M., \& Carver, C. S. (1979) Effects of person salience versus role salience on reward allocation in the dyad. Journal of Personality and Social Psychology, 37, 2071-2080.

Cohen, R. L., \& Greenberg, J. (1982) The justice concept in social psychology. In J. Greenberg \& R. L. Cohen (Eds.), Equity and justice in social behavior (pp. 1-41). New York: Academic Press.

$\rightarrow$ Cosier, R. A., \& Dalton, D. R. (1983) Equity theory and time: A reformulation. Academy of Management Review, 8 311-319.

Crosby, F. (1976) A model of egoistical relative deprivation. Psychological Review, 83, 85-113.

Crosby, F. (1982) Relative deprivation and working women. New York: Oxford University Press. 
Crosby, F. (1984) Relative deprivation in organizational settings. In B. M. Staw \& L. L. Cummings (Eds.), Research in organizational behavior (Vol. 6, pp. 51-93). Greenwich, CT: JAI Press.

Dalton, D. R., \& Todor, W. D. (1985a) Gender and workplace justice: A field assessment. Personnel Psychology, 38, 133-151.

Dalton, D. R., \& Todor, W. D. (1985b) Composition of dyads as a factor in the outcomes of workplace justice: Two field assessments. Academy of Management Journal, 28, 704 712 .

Deutsch, M. (1975) Equity, equality and need: What determines which value will be used as the basis for distributive justice? Journal of Social Issues, 31(3), 137-149.

Deutsch, M. (1985) Distributive justice. New Haven, CT: Yale University Press.

Dyer, L., \& Theriault, R. (1976) The determinants of pay satisfaction. Journal of Applied Psychology, 61, 596-604.

Festinger, L. (1957) A theory of cognitive dissonance. Evanston, IL: Row, Peterson.

Folger, R. (1977) Distributive and procedural justice: Combined impact of "voice" and improvement on experienced inequity. Journal of Personality and Social Psychology, $35,108-119$

Folger, R. (Chair) (1986, April) Fairness is more than equity: New approaches to studying organizational injustice. Symposium presented at the first annual conference of the Society for Industrial and Organizational Psychology, Chicago.

Folger, R. (1986) Rethinking equity theory: A referent cognitions model. In H. W. Bierhoff, R. L. Cohen, \& J. Greenberg (Eds.), Justice in social relations (pp. 145-162). New York: Plenum.

Folger, R. (in press) Reformulating the preconditions of resentment: A referent cognitions model. In J. C. Masters \& W. P. Smith (Eds.), Social comparison, social justice, and relative deprivation: Theoretical, empirical, and policy perspectives. Hillsdale, NJ: Erlbaum.

Folger, R., \& Greenberg, J. (1985) Procedural justice: An interpretive analysis of personnel systems. ln K. Rowland \& G. Ferris (Eds.), Research in personnel and human resources management (Vol. 3, pp. 141-183). Greenwich, CT: JAI Press.

$\rightarrow$ Freedman, S. M., \& Montanari, J. R. (1980) An integrative model of managerial reward allocation. Academy of Management Review, 5, 381-390.

Fry, W. R., \& Cheney, G. (1981, Mary) Perceptions of procedural fairness as a function of distributive preference. Paper presented at the meeting of the Midwestern Psychological Association, Detroit.
Fry, W. R., \& Leventhal, G. S. (1979, March) Cross-situational procedural preferences: A comparison of allocation preferences and equity across different social settings. In A. Lind (Chair), The psychology of procedural justice. Symposium conducted at the meeting of the Southwestern Psychological Association, Washington, DC.

Fuller, L. (1961) The adversary system. In H. Berman (Ed.), Talks on American law (pp. 10-22). New York: Vintage Books.

Furby, L. (1986) Psychology and justice. In R. L. Cohen (Ed.), Justice: Views from the social sciences (pp. 153-203). New York: Plenum.

Garland, H. (1973) The effects of piece-rate underpayment and overparyment on job performance: A test of equity theory with a new induction procedure. Journal of Applied Social Psychology, 3, 325-334.

$\rightarrow$ Goodman, P. S., \& Friedman, A. (1971) An examination of Adams' theory of inequity. Administrative Science Quarterly, 16, 271-288.

Greenberg, J. (1982) Approaching equity and avoiding inequity in groups and organizations. In J. Greenberg \& R. L. Cohen (Eds.), Equity and justice in social behavior (pp. 389-435). New York: Academic Press.

Greenberg, J. (1984) On the apocryphal nature of inequity distress. In R. Folger (Ed.), The sense of injustice (pp. 167-188). New York: Plenum.

Greenberg, J. (1986a) Determinants of perceived fairness of performance evaluations. Journal of Applied Psychology, $71,340-342$.

Greenberg, J. (1986b) Organizational performance appraisal procedures: What makes them fair? In R. J. Lewicki, B. H. Sheppard, \& M. Bazerman (Eds.), Research on negotiation in organizations (Vol. 1, pp. 25-41). Greenwich, CT: JAI Press.

Greenberg, J. (in press) Using diaries to promote procedural justice in performance appraisals. Social Justice Review.

Greenberg, J., \& Cohen, R. L. (1982) Why justice? Normative and instrumental interpretations. In J. Greenberg \& R. L. Cohen (Eds.), Equity and justice in social behavior (pp. 437-469). New York: Academic Press.

Greenberg, J., \& Folger, R. (1983) Procedural justice, participation, and the fair process effect in groups and organizations. In P. B. Paulus (Ed.), Basic group processes (pp. 235-256). New York: Springer-Verlag.

Greenberg, J., \& Leventhal, G. S. (1976) Equity and the use of overreward to motivate performance. Journal of Personality and Social Psychology, 34, 179-190.

Greenberg, J., \& Ornstein, S. (1983) High status job title as compensation for underpayment: A test of equity theory. Journal of Applied Psychology, 68, 285-297. 
Greenberg, J., \& Tyler, T. (in press) Why procedural justice in organizations? Social Justice Review.

Homans, G. C. (1961) Social behavior: Its elementary forms. New York: Harcourt, Brace, and World.

Heider, F. (1958) The psychology of interpersonal relations. New York: Wiley.

Heneman, H. G., III (1985) Pay satisfaction. In K. Rowland \& G. Ferris (Eds.), Research in personnel and human resources management (Vol. 3, pp. 115-139). Greenwich, CT: JAI Press.

$\rightarrow$ Jasso, G. (1980) A new theory of distributive justice. American Sociological Review, 45, 3-32.

LaTour, S. (1978) Determinants of participant and observer satisfaction with adversary and inquisitorial modes of adjudication. Journal of Personality and Social Psychology, 36, 1531-1545.

Lawler, E. E., III, \& O'Gara, P.W. (1967) Effects of inequity produced by underpayment on work output, work quality, and attitudes toward the work. Journal of Personality and Social Psychology, 51, 403-410.

Lerner, M. J. (1977) The justice motive: Some hypotheses as to its origins and forms. Journal of Personality, 45, 1-52.

Lerner, M. J. (1982) The justice motive in human relations and the economic model of man: A radical analysis of facts and fictions. In V. Derlega \& J. Grezlak (Eds.), Cooperation and helping behavior: Theories and research (pp. 121-145). New York: Academic Press.

Lerner, M. J., \& Whitehead, L. A. (1980) Procedural justice viewed in the context of justice motive theory. In G. Mikula (Ed.), Justice and social interaction (pp. 219-256). New York: Springer-Verlag.

Leventhal, G. S. (1976a) Fairness in social relationships. In J. W. Thibaut, J. T. Spence, \& R. C. Carson (Eds.), Contemporary topics in social psychology (pp. 211-239). Morristown, NJ: General Learning Press.

Leventhal, G. S. (1976b) The distribution of rewards and resources in groups and organizations. In L. Berkowitz \& E. Walster (Eds.), Advances in experimental social psychology (Vol. 9, pp. 91-131). New York: Academic Press.

Leventhal, G. S. (1980) What should be done with equity theory? In K. J. Gergen, M. S. Greenberg, \& R. H. Willis (Eds.), Social exchange: Advances in theory and research (pp. 27-55). New York: Plenum.

Leventhal, G. S., Karuza, J., \& Fry, W. R. (1980) Beyond fairness: A theory of allocation preferences. In G. Mikula (Ed.). Justice and social interaction (pp. 167-218). New York: Springer-Verlag.

Leventhal, G. S., \& Michaels, J. W. (1969) Extending the equity model: Perceptions of inputs and allocation of reward as a function of duration and quantity of performance. Journal of Personality and Social Psychology, 12, 303-309.
Lind, E. A., Kurtz, S., Musante, L., Walker, L., \& Thibaut, J. W. (1980) Procedure and outcome effects on reactions to adjudicated resolution of conflicts of interest. Journal of Personality and Social Psychology, 39, 643-653.

Lind, E.A., \& Tyler, T.R. (in press) The social psychology of procedural justice. New York: Plenum.

Mahoney, T. A. (1975) Justice and equity: A recurring theme in compensation. Personnel, 52(5), 60-66.

$\rightarrow$ Mahoney, T. A. (1983) Approaches to the definition of comparable worth. Academy of Management Review, 8, 14-22.

Martin, J. (1981) Relative deprivation: A theory of distributive injustice for an era of shrinking resources. In L. L. Cummings \& B. M. Staw (Eds.), Research in organizational behavior (Vol. 3, pp. 53-107). Greenwich, CT: JAI Press.

Messé, L. A. (1971) Equity in bilateral bargaining. Journal of Personality and Social Psychology, 17, 287-291.

Mikula, G. (1980) On the role of justice in allocation decisions. In G. Mikula (Ed.), Justice and social interaction (pp. 127-165). New York: Springer-Verlag.

Miner, J. B. (1984) The unpaved road over the mountains: From theory to applications. Industrial-Organizational Psychologist, 21(2), 9-20.

Montada, L., Schmitt, M., \& Dalbert, C. (1986) Thinking about justice and dealing with one's own privileges: $A$ study of existential guilt. In H. W. Bierhoff, R. L. Cohen, \& J. Greenberg (Eds.), Justice in social relations (pp. 125-143). New York: Plenum.

Pritchard, R. A. (1969) Equity theory: A review and critique. Organizational Behavior and Human Performance, 4, 75-94.

Pritchard, R. D., Dunnette, M. D., \& Jorgenson, D. O. (1972) Effects of perceptions of equity and inequity on worker performance and satisfaction. Journal of Applied Psychology, 56, 75-94.

Reis, H. T. (1986) Levels of interest in the study of interpersonal justice. In H. W. Bierhoff, R. L. Cohen, \& J. Greenberg (Eds.), Justice in social relations (pp. 187-209). New York: Plenum.

Schwinger, T. (1980) Just allocations of goods: Decisions among three principles. In G. Mikula (Ed.), Justice and social interaction (pp. 95-125). New York: Springer-Verlag.

Schwinger, T. (1986) The need principle of distributive justice. In H. W. Bierhoff, R. L. Cohen, \& J. Greenberg (Eds.), Justice in social relations (pp. 211-225). New York: Plenum.

Sheppard, B. H. (1984) Third party conflict intervention: A procedural framework. In B. M. Staw \& L. L. Cummings (Eds.), Research in organizational behavior (Vol. 6, pp. 141-190). Greenwich, CT: JAI Press. 
Sheppard, B. H. (1985) Justice is no simple matter: Case for elaborating our model of procedural fairness. Journal of Personality and Social Psychology, 49, 953-962.

Sheppard, B. H., \& Lewicki, R. J. (in press) Toward general principles of managerial fairness. Social Justice Review.

Stouffer, S. A., Suchman, E. A., DeVinney, L. C., Star, S. A., \& Williams, R. M., Jr. (1949) The American soldier: Adjustment during Army life (Vol. 1). Princeton, NJ: Princetor University Press.

Thibaut, J., \& Walker, L. (1975) Procedural justice: A psychological analysis. Hillsdale, NJ: Erlbaum.

Thibaut, J., \& Walker, L. (1978) A theory of procedure. California Law Review, 66, 541-566.

$\rightarrow$ Tornblom, K.Y., \& Jonsson, D.R. (1985) Subrules of the equality and contribution principles: Their perceived fairness in distribution and retribution. Social Psychology Quarterly, $48,249-261$.

Tyler, T. R., \& Caine, A. (1981) The role of distributional and procedural fairness in the endorsement of formal leaders. Journal of Personality and Sociai Psychology, 41, 642-655.
Tyler, T. R., \& Folger, R. (1980) Distributional and procedural aspects of satisfaction with citizen-police encounters. Basic and Applied Social Psychology, 1, 281-292.

Van Avermaet, E., McClintock, C., \& Moskowitz, J. (1978) Alternative approaches to equity: Dissonance reduction, pro-social motivation and strategies accommodation. European Journal of Social Psychology, 8, 419-437.

$\rightarrow$ Walker, L., Lind, E. A., \& Thibaut, J. (1979) The relation between procedural justice and distributive justice. Virginia Law Review, 65, 1401-1420.

Walster, E., Berscheid, E., \& Walster, G. W. (1973) New directions in equity research. Journal of Personality and Social Psychology, 25, 151-176.

Walster, E., Walster, G. W., \& Berscheid, E. (1978) Equity: Theory and research. Boston: Allyn \& Bacon.

Walton, R. W., \& McKersie, R. B. (1965) A behavioral theory of labor negotiations. New York: McGraw-Hill.

$\rightarrow$ Weick, K. E. (1966) The concept of equity in the perception of pary. Administrative Science Quarterly, 11, 414-439.

Weiner, N. (1980) Determinants and beharvioral consequences of pay satisfaction: A comparison of two models. Personnel Psychology, 33, 741-757.

Jerald Greenberg (Ph.D., Wayne State University) is Associate Professor of Management and Human Resources at Ohio State University. Correspondence regarding this article may be addressed to him at: Faculty of Management and Human Resources, Ohio State University, 1775 College Road, Columbus, $\mathrm{OH}$ $43210-1399$. 